INFORMASI: Kajian Ilmu Komunikasi-ISSN (p) o126-065o; ISSN (e) 2502-3837

Vol. 48. No. 2 (2018). Pp.169-179. doi: https://doi.org/10.21831/informasi.v48i2.21657

\title{
HEGEMONIC MASCULINITY IN ARCHETYPAL AFRICAN NOVELS
}

\author{
Amjad Alsyouf \\ amjad.alsyouf@bau.edu.jo \\ Ajloun University College \\ Al-Balqa Applied University, Jordan.
}

\begin{abstract}
The study attempts to examine the concept of hegemonic masculinity in Tayeb Salih's Season of Migration to the North (1966) and Chinua Achebe's Things Fall Apart (1958). To achieve that it deals with two concerns. First, it tackles the process of development of masculinity attempting to identify hegemonic masculinity among other stages within this process. Secondly, it investigates hegemonic masculinity as a concept occasionally occurs in popular African fiction with emphasis placed on its presence in Salih's Season of Migration to the North and Achebe's Things Fall Apart. The research concludes with a recommendation to focus more research efforts on literature that deals with hypermasculinity, the stage succeeding hegemonic masculinity, as it needs immediate consideration due to its critical impact on contemporary world and audience.
\end{abstract}

Keywords: Hegemonic Masculinity, Season of Migration to the North, Things Fall Apart.

\section{HEGEMONI MASKULINITAS DALAM NOVEL-NOVEL ARCHETYPAL AFRICAN}

\begin{abstract}
Abstrak
Penelitian yang bertujuan untuk mengkaji konsep mengenai hegemoni maskulinitas di Tayeb Salih's Season of Migration to The North (1996) dan Chinua Achebe's Things Fall Apart (1958) ini berfokus pada dua hal. Pertama, mengkaji proses perkembangan maskulinitas untuk mengidentifikasi hegemoni maskulinitas. Kedua, menginvestigasi hegemoni maskulinitas sebagai sebuah konsep yang selalu muncul dalam karyakarya fiksi afrika dengan penekanan pada Salih's Season of Migration to The North and Achebe's Things Fall Apart. Penelitian ini memberikan simpulan dan rekomendasi pada fokus penelitian selanjutnya yang berkaitan dengan hipermaskulinitas, seperti suksesnya hegemoni maskulinitas yang perlu dipertimbangkan penelitiannya karena dampak yang kritis dari dunia dan audiens saat ini.
\end{abstract}

Kata Kunci: Hegemoni Maskulinitas, Season of Migration to the North, Things Fall Apart. 


\section{INTRODUCTION}

The reception of Africa as mysterious and savage continued until the nineteenth century when Europe beheld it as a dark continent. Its interior was unjustifiably predicted as murky, obscure, and dangerous; its inhabitants were characterized by otherness and inferiority. Those negative notions have long affected the world's perception of Africa and its people, and influenced the literature written to depict its life. Different works of fiction, as some of Joseph Conrad's and J. M. Coetzee's narratives, have portrayed the African life as savage, harsh, aimless, and frequently connected with gender prejudice and patriarchal dominancy. The African novelists, in like manner, have reflected a parallel gloomy view of their continent in their writings. Two major examples in this respect are Tayeb Salih's Season of Migration to the North (1966) and Chinua Achebe's Things Fall Apart (1958).

The treatment of the African life in Salih's and Achebe's novels, particularly their presentation of the African people and the male/female relationships, is determined by the authors' analogous celebration of the patriarchalauthorityin the Sudaneseand Igbo societies respectively, the identical themes they address in the novels, and the influence western thought and literature exerts on the writings of the two novelists. These factors play a fundamental role in determining the gender roles and relationships in the novels, and locate the African fiction within an increasing universal writing trend of hegemonic masculinity.

Salih and Achebe interestingly share comparable fictional presentation of the male/female relationships manifested in their creation of superordinate male characters whose dominating powers nourish the suppression and exclusion of the subordinate female ones. The fictitious superordinate males passionately accept the privilege of masculine supremacy bestowed upon them as it arouses their confidence and delight to the detriment of the suppressed females who often suffer silently and sorely. The males' pursuit of domination is frequently achieved through violent actions. The violence they practice is either physical, as portrayed in Achebe's Things Fall Apart, or sexual as reflected in the speeches and actions of certain male characters in Season of Migration to the North.

The authors' parallel thematic orientation is demonstrated in the image of the subordinate African female who the novels introduce as persecuted and reluctantly absent. The subordination and exclusion imposed on women occasionally trigger particular reaction. The feminine reaction however is not identical in the two novels. The pervasiveness of the masculine powers and dominance in Season of Migration to the North provokes particular female characters to make hard attempts, even drastic ones, to resist male's dominancy. The feminine resisting reaction stimulated to challenge the masculine dominating practices in Achebe's Things Fall Apart is however peaceful and nonconfrontational.

Both Salih and Achebe were influenced by the western thought and literature that formed part of their artistic and literary consciousness. Salih "was well-versed in English literature and thought," and his novel Season of Migration to the North reflects the influence of Fanon and Freud on his perceptions and writings (Viene 2017). "Achebe was influenced by several factors such as the Western literary tradition, traditional African stories, Western education and Christianity..." (Bamisile 2008, 255). Western literature and thought have become distinguishing features the two novels reflect as they have major impact on their writers. These features have supposedly helped the works to be well-received by the western audiences and have placed them among the major works of fiction introduced in the modern era.

Against this background this paper aims to examine the presentations of aspects of masculinity and femininity in Salih's Season of Migration to the North and Achebe's Things Fall Apart with an attempt to define 
the gender roles in the novels. This will be achieved through placing particular emphasis on the concept and practices of hegemonic masculinity as metaphorically displayed by the two novelists who are considered major African literary voices. The paper will make use of the cultural perspective in its efforts to explain, and broaden the examination of, the concept of hegemonic masculinity by tracing its emergence and development, thus determining its position as subsequent to masculinism and masculism, and precedent to hypermasculinity.

\section{LITERATURE REVIEW}

\section{From Masculinism to Hypermasculinity}

Cultural history offers adequate support for the research efforts sought to identify the nature and development of masculinity in literature. The examination of the progress of world thoughts and cultures manifests the universalness of the treatment of aspects of masculinity. Certain cultural historians argue about the inevitability of its occurrence in humans' thoughts and actions. Cultural historian Richard Tarnas (1996) places emphasis on the pervasiveness of the powers of masculinity and its impact on the western thought. We read in his book The Passion of the Western Mind that "the masculinity of the Western mind has been pervasive and fundamental, in both men and women, affecting every aspect of Western thought, determining its most basic conception of the human being and the human role in the world" (Tarnas 1996, 441). So far as Tarnas's view is concerned, masculinity is perceived as a prevailing hard-to-localize power. It stresses the need for a universal examination of its applications and effects. Tarnas highlights the strong influence masculinity has over human thoughts and actions disregarding gender or location. His argument calls for an analytical investigation of the nature, background, and progress of the concept. English literature can function as a threshold in this context due to the universality it enjoys. Its body contains the necessary knowledge needed to identify early stages of masculinity in literature; hence a comprehensible understanding of the concept is potentially developed.

One way to understand masculinity is through the examination of its progress. It has practically gone through four stages of development in literature. The first and earliest stage is masculinism where a dominant male figure/s often plays an essential role in the development of the plot through exercising supreme masculine powers over other characters. Ferrell Christensen (2005) defines masculinism as the promotion of the attributes of manliness (in Honderich, 2005, 528). Different authors have shown inclinations to this central-hero pattern from early periods of the history of literature. Old English literature is a case in point. Beowulf is a perfectly masculine world that ignores the role of women as social beings in a society structured on the belief in the heroic attributes of its male warriors whose action is the only determiner of the progress of events. Unlike their role in later literature, women at this stage do not need to engage in a perpetual encounter with men as a way to experience the negative effects of masculinity on them; the fate of women, men, and even of the world at this phase is entirely determined by the masculine hero.

The second stage is masculism. Christensen (2005) defines masculism as "promoting the interests or rights of men" $(2005,528)$. This stage is a transformation of the previous one, and has contributed to later periods of literary production. The powers that determine the role of males and females in the society at this stage are nourished by a masculine tendency to promote the importance of the presence of men and negligence of women in the public sphere. In her argument over the gender roles in seventeenth-century England, Gabriele Rippl (2011) states that

It is clear that seventeenth-century England fostered gender roles that were linked to two complementary but separate emerging spheres: the public and the private. The public sphere belonged mainly, but not exclusively, to men, whereas the private sphere, 
the space of the home, of childbearing and simple piety, was considered to be feminine preserve. (Rippl 2011, 71)

Rippl's view places the British women of the seventeenth century, most probably those who are not aristocrats, within a limited, or even hidden, domestic sphere of household and childbearing on the one hand. On the other hand it stresses the strong public presence and freedom seventeenth-century men enjoy compared to women. The role of the male at this stage has changed from determining the fate of his world to publicly disclosing his interests and likes, a privilege of which women are deprived.

The exclusion of women and prominence of men in the public sphere has continued to nineteenth-century England. Alfred, Lord Tennyson's narrative verse "The lady of Shallot" is a significant representation of the concept of masculism in this context. The work is centered around the Lady of Shallot who is not permitted to enjoy or even have a look at the external public world where men and aristocrats spend merry times. Tennyson's fictitious work reflects a realistic view of the Victorian age, and introduces the reader to a late example of masculism in literature.

Hegemonic Masculinity occupies the third stage of the development of the applications and practices of masculinity. Several attempts have been pursued by different scholars to examine and identify this concept. Robert Morrell, Jewkes, and Lindegger (2012) in "Hegemonic Masculinity/Masculinities in South Africa: Culture, Power, and Gender Politics," define hegemonic masculinity in academic work as the concern with "acknowledging the power that men had over women" (Morrell, Jewkes, and Lindegger 2012, 11). They highlight its association with "oppressive attitudes and practices" $(2012,11)$. At this stage of literary production the male dominating characters are no more content with having their attributes and interests promoted, but tend to exercise effective hegemonic practices over females as a way of im/proving masculinity. Morrell, Jewkes, and Lindegger (2012) add that hegemonic masculinity is "widely used in South African gender research" (12). Masculinity has explicitly developed and travelled in the twentieth century to localize in African literature after proving former presence in other certain cultures.

Jeff Hearn (2004) has also investigated the concept of hegemonic masculinity. $\mathrm{He}$ offers a comprehensive examination of masculinity and its treatment within the field of critical studies on men. Hearn distinguishes different modes of men's power in the process of analyzing gendered power and men's relations to power and dominance; nevertheless he has not clearly displayed the chorological development of those modes or their sequential presence in early and later literature. We read in his work

What is at issue here is the persistent presence of accumulations of power and powerful resources by certain men, the doing of power and dominance in many men's practices, and the pervasive association of the social category of men with power. Men's power and dominance can be structural and interpersonal, public and/or private, accepted and taken-for-granted and/or recognized and resisted, obvious or subtle. It also includes violations and violences of all the various kinds. (Hearn 2004, 51)

Hearn's classification of the modes of men's power and dominance corresponds to the three stages of the development of masculinity already treated in this research, where masculinism is reflected through the structural and interpersonal modes of power and masculism through the public. Hegemonic masculinity in this context is relevant to all the modes proposed in Hearn's study.

Hearn's modes of men's power and dominance have become misleadingly practiced and illusively re-presented in late twentieth and twenty-firstcenturies' writings. A newstage of the development of masculinity has been sought then, especially with the emergence of Hypermasculinity. Ronald O. Craig (2009) defines hypermasculinity as "an adoption of extreme machismo in males" (in 
Gabbidon, and Greene 2009, 366). The new principal authority governing all modes of power and the men really practicing them, and those charged of abusing them, at this stage has come to be the media and particular fictional works. They have occasionally played a misinforming role where the distribution and localization of men's power and dominance in the world has been blurred and confusing to determine. Literature and media, consequently, have manipulated the belief in hypermasculinity by reconsidering the powers certain men display as devastating and terrifying. The discourse they create unjustifiably and suspiciously re-presents the hypermasculine powers as exploited by particular groups around the world for goals serving certain agendas.

In "Criminal Justice Implications of the Macho Personality Constellation" Matt C. Zaitchik, and Mosher (1993) argue that hypermasculinity is associated with the macho personality construct that "consists of the view of violence as manly, the view of danger as exciting, callous sexuality toward women, and toughness as selfcontrol" (Zaitchik, and Mosher 1993, 227). These aspects have been manipulated by world media and literature either to focus on the hypermasculinity of certain targeted groups apart from its existence in others, or to attribute them to particular races or organizations for national or international security purposes. This notion has been the subject of A. Bilgic's (2005) "Hybrid Hegemonic Masculinity of the EU before and after the Arab Spring: A Gender Analysis of Euro-Mediterranean Security Relations" in which he writes

After the Arab Spring, the EU [European Union] has been determined to maintain the status quo by re-constructing these gendered power relations [between the hybrid hegemonic masculinity of the EU (bourgeois-rational and citizenwarrior) and the subordinate (both feminized and hypermasculinized) Southern neighborhood]. This gender analysis contributes to the literature on Euro-Mediterranean relations through its specific focus on the (re)construction processes of gendered identities within the West/non-West context in tandem with EU's competing notions of security. (Bilgic 2015, 1)

The reconstruction of gendered identities within the West/non-West context has for its main objectives reconstructing the world-view of the non-Western ordinary man to be rather received as hypermasculinized, characterized by terrorist behavior and practices. Contemporary fiction about terrorism is a clear manifestation of this conception, and a practical example of hypermasculinity - the contemporary phase of masculinity.

\section{METHODS}

The paper focuses on the presentation of the male/female relationships, roles and place in the narration of the novels. Their speeches, silences and actions will be examined with reference to the concept of hegemonic masculinity that will be culturally approached and investigated. The paper therefore makes use of the cultural studies so as to clearly define the concept of hegemonic masculinity. It will identify the different stages of its development, and determine its position among other relevant notions. After the concept of hegemonic masculinity is well studied and defined, the paper will deal with the novels by examining their contextual treatment and involvement of hegemonic masculinity.

\section{RESULTS AND DISCUSSION}

\section{Hegemonic Masculinity in Season of Migration to the North and Things Fall Apart}

In the process of its development formerly investigated, masculinity has changed and travelled in the twentieth century to localize in African literature. Modern African fiction has substantially contributed to the emergence and identification of hegemonic masculinity. Salih's Season of Migration to the North and Achebe's Things Fall Apart represent two examples of fictional works 
that demonstrate hegemonic masculine tendenciesthrough highlighting thepervasive presence of superordinate male characters in the African literary body. Hearn's modes of power and dominance are practiced by the hegemonic masculine characters of Salih's and Achebe's works, particularly the two major characters Wad Rayyes and Okonkwo who, respectively, embody the concept of hegemonic masculinity in the novels.

The hegemonic tools used in Salih's and Achebe's novels vary between the exercise of sexual, or of physical violence over female characters. Sexual violence is a determining element that controls the thoughts and actions of male characters in Salih's Season of Migration to the North, while physical violence is a dominating power characterizing certain male characters in Achebe's Things Fall Apart. These hegemonic tools are the subject of the argument of the cultural critic Friedrich Nietzsche (1969). In his book Thus Spake Zarathustra Nietzsche comments on the gender role arguing that "man shall be trained for war, and woman for the recreation of the warrior" (Nietzsche 1969, 52). Although his view could be an articulation of a particular situation, still it is valid to determine the stereotype of man and woman in world literature as it is widely adopted in literary works including Salih's and Achebe's novels. The character of Okonkwo in Things Fall Apart is a reflection of the Nietzschean oppressive warrior, whereas Salih's Wad Rayyes is more satisfied with the delight brought by the Nietzschean woman.

Wad Rayyes is a controversial character that conceivably stands for the concept of hegemonic masculinity in Salih's Season of Migration to the North. The reader can recognize in this aged man a seeker of sexual pleasure. The narrator comments on his demeanor telling that he "had been much married and much divorced, taking no heed of anything in a woman except that she was woman, taking them as they came, and if asked about it replying, 'A stallion isn't finicky"' (Salih 1976, 79). Wad Rayyes's statement signifies his obsession with the subordination and wielding of women. The narrator adds that he often recounts "to people the details of his intimacies" with his wives $(1976,79)$. Building on his speech and attitudes, marriage for Wad Rayyes is by no means sought for domesticity, but rather a way to please his sexual desires and a revelation of his love for hegemony.

Wad Rayyes furthermore deals with marriage as a manifestation of a firm belief in the worth of hegemonic masculinity. A proof is found in his insistence on marrying Hosna Bint Mahmoud, the representation of the rebellious-victimized female in the novel, who turns his proposal down. Wad Rayyes comments on her refusal

'I shall marry no one but her,' he said. 'She'll accept me whether she likes or not. Does she imagine she's some queen or princess? Widows in this village are more common than empty bellies. She should thank God she's found a husband like me. (97)

He consequently represents a fanatic patriarchal society impatient to women's self-reliance. His attitudes show gendered discrimination, desire for domination, oppressiveness, and hegemonic tendencies.

While the Sudanese woman in Salih's novel is a victim of masculine sexual desires, the Igbo woman in Achebe's Things Fall Apart suffers of a patriarchal physical violence. Chimalum Nwankwo (2001) argues that "the nature of the crisis in society determines the character of representation. In the case of the traditional Igbo society, the concept of power and the modes of power are essential" (Nwankwo 2001, 82). Nwankwo's argument recalls Hearn's modes of power that are embodied in the character of Ukonkwo, the protagonist of Things Fall Apart and the representative of the concept of patriarchal authority in the Igbo society. Like Wad Rayyes, he is an obvious articulation of the concept of hegemonic masculinity and suppression of femininity. His character plays the most essential role in the development of the plot through the tendencies he reveals for subordination of females, and even of males 
who show feminine inclinations.

Ukonkwo's hegemonic violent desires appear early in the novel, and early in his life. He has brought honor to his village when he was young by beating "Amalinze the Cat" in a wrestling contest. This incident on the one hand demonstrates Ukonkwo's possession of violent powers. On the other hand the use of the name "Cat" is not incidental; it is a clear symbol of femininity. The fighting scene therefore is an implication of Ukonkwo's early and serious attempts to subordinate femininity in the novel's world.

Ukonkwo's attitudes in the novel also reveal a misogynist character. He is presented in different places beating his wives "heavily" for trivial causes. He believes that violence and oppressiveness are an expression of masculinity, and feelings of sympathy are signs of weakness and femininity, and even a source of dishonor. He could hurt himself as a retribution for allowing any feminine attributes to steal into his thought. The scene of killing Ikemefuna in this respect is an obvious manifestation of his belief in the value of hegemonic masculinity, and rejection and hatred for femininity. Debbie O'Neill (n.d.) states that

Behind his (Okonkwo's) facade of confidence in his male resolve he is profoundly uncomfortable in the presence of femininity... Ikemefuna's obvious artistic abilities and lively temperament would only exist for a time before Okonkwo would be forced to repress them for fear of them becoming womanly. (O’Neill, n.d.)

In this context, the ritualistic event of killing Ikemefuna in the novel is perceived as an allegorical extermination of femininity in favor of the rise of the patriarchal authority, thus a metaphorical triumph of hegemonic masculinity.

The attempt to terminate the feminine presence in Achebe's novel is also promoted by employing metaphors of female absence. Florence Stratton (2007) pinpoints that "women are largely absent from positions of power and are consistently marginalized and silenced in Things Fall Apart" (in Whittaker, and Msiska 2007, 104). Women do not enjoy significant involvement in the cultural, political or social aspects of the life of the novel. They are even forbidden from contributing to activities regarded as their personal concern. Rose Ure Mezu (n.d.) draws attention to the misery of the absent African female in Achebe's Things Fall Apart. We read in her work

It is an andocentric world where the man is everything and the woman nothing... African women languished on the fringe of their universe- neglected, exploited, degenerated, and indeed made to feel like outsiders. They were not invited to stay when men were engaged in any discussion... (Mezu, n.d.)

The trial scene is evident in this regard. The novel narrates "It was clear from the way the crowd stood or sat that the ceremony was for men. There were many women, but they looked on from the fringe like outsiders" (Achebe 2008, 62). The scene metaphorically illustrates the formation of the structure of power in the society where the women play a very insignificant role.

The picture of the women forced to hide from the world of Things Fall Apart is mirrored in Season of Migration to the North. The narrator of Salih's novel doesn't wait for long to inform the reader that the world of the novel is entirely masculine. He claims the superiority of men right from the first line where he addresses his speech specifically to them; "It was, gentlemen, after a long absence..." (Salih 1976, 1). The narrator re-emphasizes the masculinity of the novel's world once again when he later claims men as his sole audience calling them "dear sirs." The novel's dominating character Wad Rayyes also helps the narrator in his efforts to establish a masculine hegemonic world that positions women on the margins of power. In his commentary on the issues of the village Wad Rayyes brags "in this village the men are guardians of the women" (1976, 98), a statement Mahjoub, a friend of the narrator, clarifies saying "you know how life is run here... women belong to men" 
(99). The men of the novel enjoy a game of power monopolization aiming to construct a hegemonic patriarchal world.

In "Sexual Politics: Women in Season of Migration to the North" Evelyn Accad (1985) stresses the patriarchal nature of Salih's novel stating that "women remain the real victims of... games of power and seduction" (Accad 1985, 55). The terminology the narrator employs to describe women in this context is significant in nourishing notions of absence and subordination. Women are introduced in the novel as objects that "belong" to men, "servants" of them, and incapable of making decisions on their own. They are even forced to do what the male characters exactly desire, though reluctantly, such as the case when Hosna Bint Mahmoud is forced to marry Wad Rayyes.

Like Salih's Season of Migration to the North, Achebe's Things Fall Apart nourishes notions of negligence, degradation, and dehumanization of women in favor of hegemonic masculinity. Females in the novel are bought and sold to marriage. In one incident a marriage proposal turns to a commercial bargain. A suitor proposes to marry Akueke, the beautiful daughter of Okonkwo's best friend Obierika. While Obierika and his eldest brother Machi negotiate Akueke's bride-price, it turns to a bargain in which Machi claims they do not want "to go below thirty" (Achebe 2008, 51). He adds "but as the dog said, 'if I fall down for you and you fall down for me, it is a play"' (Achebe, 2008). The bargain goes on to be finally settled at "2o bags of cowries" (2008, 51). He acts as a trader exposing cheap goods to sell. Machi insists again that "marriage should be a play" (51). After the deal is done, women of the household come to serve drink and food. The scene brings dishonor and humiliation to women, and reflects the arrogance of men. Men negatively determine women's fate; in the meantime women just say nothing to contribute to theirs, and are content to serve and please men. This scene is crucial in solidifying the powers of hegemonic masculinity.

\section{Rebellious Femininity}

On the ground that African women in Season of Migration to the North and Things Fall Apart are victims of the suppressive practices of hegemonic masculinity, they occasionally show resisting reaction. The feminine resistance in the novels is often peaceful. John Wakota (2014) distinguishes two categories of reaction the African rebel female produces in fiction works to resist male dominancy:

The first category is manifested through female characters' running away from oppressive situations... The second category has characters that, as a way of bargaining, ply between submissiveness and rebelliousness and eventually graduate in one of the two groups. According to the advocates of the bargaining approach reviewed above, submissiveness or rebelliousness is a matter of choice by the character, provided it is part of their self-realization project. (Wakota 2014, 34)

However, the observer of Salih's Season of Migration to the North would identify a third category where women's rebelliousness often becomes self-destructive.

The mentality of men who belong to patriarchal societies is drastically unchangeable. This calls some women to drive the wheel of change and construct a struggle for self-realization. The African women the novels present seek a rational process of change that aims at saving the day and preserving the family. Nevertheless, the absence of the familial structure would not help women to steer clear of violence. The family therefore is a stabilizing force in the novels. This point is clear when the character of Ekwefi, Okonkwo's wife in Things Fall Apart, is compared to Hosna Bint Mahmoud, the widow who turns down Wad Rayyes's humiliating marriage proposal in Season of Migration to the North. While Ekwefi works hard to save her family bonds, Hosna would pay no attention to the consequences of a possible radical reaction against Wad Rayyes who is in no means a significant person in her life. 
Hosna is a free woman who believes in marriage as a stabilizing bond based on love and domesticity. She refuses to become a victim of Wad Rayyes's manly hegemonic desires. Mahjoub portrays his behavior in an interesting manner: "Wad Rayyes will certainly become obsessed with some other woman. Let's suppose, at the very worst, she marries him; I don't think he'll live more than a year" (Salih 1976, 103). Hosna, a revolutionary figure committed to her cause as a woman and as a human being in the first place, symbolically kills him and then herself in a rebellious manner. Her rebellion is aggressive and fatal, and brings disaster to her life. The violence she displays, however, essentially targets the social tenets of patriarchy rather than the man as a flesh. It aims at reestablishing the foundations of gender roles and relations in her society.

Although homicide and suicide are irrational and self-destructive, they are metaphorically reasonable in the context of the novel. Mona Takieddine-Amyuni (1985) depicts Hosna as a representation of the positive change of the place of woman in the patriarchal societies after long time of suppression and subordination. She argues that:

Hosna is the precursor of the future woman of the Sudan, for she is not allowed to live her present, to live her life. She is treated as an indecent, mad, citified woman by a conservative male society that condones Wad Rayyes's senile demands over her. (Amyuni 1985, 35)

Jalāl El-'Ashrī (1981), in the same vein, treats the character of Hosna as a symbol of the new civilized world that refuses the negative hegemonic masculine practices. Hosna kills Wad Rayyes thus as a revolt against all outdated traditions of patriarchal hegemony in modern societies (El-'Ashrī 1981, 165).

From one point of view, Hosna is a representation of the anxious African female who bears the burden of hegemonic masculinity and finds herself obliged to fight against its forces. From another point of view she is the feminine voice of freedom and integrity, and the wind of change that seeks to uproot the patriarchal hegemonic conventions. Wail S. Hassan (2003) points out that:

$$
\begin{aligned}
& \text { Hosna dares the unthinkable-and, } \\
& \text { for the villagers, the unspeakable. } \\
& \text { Her retaliation against the abuses of } \\
& \text { patriarchy-her castration and killing } \\
& \text { of Wad Rayyes, who represents the } \\
& \text { worst aspects of traditional culture- } \\
& \text { is payback in kind for her own genital } \\
& \text { mutilation, which until then had been } \\
& \text { the subject of casual remarks and jokes } \\
& \text { for the village patriarchs, though a } \\
& \text { taboo subject in Arabic literature and } \\
& \text { in public discourse generally. (Hassan } \\
& \text { 2003, 87) }
\end{aligned}
$$

A confirmation of the feminine rejection of the hegemonic masculine tradition in the novel in this regard is articulated through Bint Majzoub, Wad Rayyes's elder wife, who shows no affections for his death.

Ekwefi, just like the other African women, does not take part openly in the public affairs. Her disposition is often tranquil and peaceful. Nevertheless Nnaemeka portrays her as a distinct example of a female's rebelliousness in African literature (Nnaemeka 1995, 92). In times of adversity she would spare no efforts to overcome the bottleneck. Chimalum Nwankwo (2001) argues that "when the traditional Igbo woman decides to act, she acts" (Nwankwo 2001, 82). Ekwefi in this context develops a reaction relevant to the life situation she encounters. E. N. Njaka (2001) comments on the behavior of the Igbo women stating that they "must not sit quietly when the Constitution is violated and the land goes ablaze" (in Nwankwo 2001, 82). Perils motivate the African woman's intervention, a behavior perceived as rebellious by the African Igbo society. Compared to Hosna however, Ekwefi's rebellion is different. She reacts with relevant violence only in cases of defending her family and saving their lives.

The loss of Ekwefi's daughter Ezinma is a case in point. Ekwefi reveals a feminine reaction that is not specifically rebellious to hegemonic masculinity, but alert to the endangering situations threatening her 
family. She decides to follow Chielo the goddess who has taken her daughter away, though violating the will of her husband and the local gods, only to save the life of Ezinma. This incident does not only prove the incredibleness of Okonkwo's perception of femininity as weak and untrustworthy, but also demonstrates the feminine qualities repressed by powers of hegemonic masculinity; qualities that women can employ in times of distress and dangers for the good of the family and the society.

\section{CONCLUSION}

Hegemonic masculinity is a stage of a developing process of a universal masculinity. Scholarship dealing with it can assist the research efforts to better recognize male/ female relationships with the goal of solving gender debate issues. Nonetheless aspects of hegemonic masculinity are essentially centered in the African world so far as the twentieth century novel is concerned. Gender studies therefore need to develop a comprehensive view based on the fact of the perpetual change and progress of masculinity that has been adopting new phases over time. Perhaps the need of a particular age for research on masculinity is determined by its peculiar aspects basically reflected in the works of its contemporary writers. Those works are verbal manifestations reflecting the necessity to treat new phases of masculinity so as to deal with critical questions related to the age.

Masculinity is a growing system not restricted to hegemonic masculinity which is but one tile in the mosaic structure of masculine practices reflected in life, literature and other writings. Masculinity has been probably adopting more devastating tools as it advances in time and geography. When comparing the recent irrational hegemonic practices that belong to times of post-hegemonic masculinity to aspects of twentieth century hegemonic masculinity as gender roles and patriarchal practices we conclude that it is crucial to call for concentrating appropriate research efforts on post-hegemonic masculinity, earlier called hypermasculinity, as it has become an influential power in the recent times.

Hegemonic masculinity needed particular consideration at a certain period of time, specifically before the recent insanities of the $21^{\text {st }}$ century world. It has exerted influence over specified societies and females groups, whilst entire countries currently suffer under the yoke of hypermasculinity. The practices and texts reflecting hypermasculinity have developed an emergent need for immediate consideration as they critically affect the present world contrasted to aspects of hegemonic masculinity which impact is limited nowadays. Focusing more research on hypermasculinity has been therefore necessary to help the scholars and populace to develop improved perspectives of life aiming to make it possible in a hypermasculine tyrannous universe.

\section{REFERENCES}

Accad, Evelyn. (1985). "Sexual Politics: Women in Season of Migration to the North". In M. T. Amyuni (Ed.) Season of Migration to the North by Tayeb Salih: A Casebook, edited by Mona Takieddine Amyuni, Beirut: American University of Beirut.

Achebe, Chinua. (2008). Things Fall Apart, Nairobi: East African Educational Publishers Ltd.

Bamisile, Sunday Adetunji. (2008). "SocioCultural Commitment in Things Fall Apart", Africana Studia: Revista Internacional de Estudos Africanos, Vol. 11, No. 1, pp. 247-264.

Bilgic, Ali. (2015). "Hybrid Hegemonic Masculinity of the EU before and after the Arab Spring: A Gender Analysis of Euro-Mediterranean Security Relations", Mediterranean Politics, Vol. 20, No. 3, pp. 322-341.

Hassan, Wail S. (2003). Tayeb Salih: Ideology $\mathcal{E}$ the Craft of Fiction. New York: Syracuse University Press.

Honderich, Ted. (2005). The Oxford Companion to Philosophy. Oxford: 
Oxford University Press.

El-'Ashrī, Jalāl. (1981). “Zūrba Assūdanī aw Albaḥth 'an Aldat Alafrikiyyah [The Sudanese Zurba, or the Searching for the African Self]". In Ahmad Said Mohammadiyya et al. (Eds.) Al-Tayyeb Saleh: 'Abqari Arriwaiah Al-Arabiyyah [Al-Tayyeb Saleh: The Arabic Novel's Genius], Beirut: Dār El-'Awda.

Gabbidon, Shaun L. \& Greene, Helen Taylor. (2009). Encyclopedia of Race and Crime, Los Angeles: Sage.

Hearn, Jeff. (2004). "From Hegemonic Masculinity to the Hegemony of Men”, Feminist Theory, Vol. 5, No. 1, pp. 49-72.

Mezu, Rose Ure. (n.d.). "Women in Achebe's World", Womanist Theory and Research Journal, http://www.athenscsd.org/ userfiles/37/Classes/972/women\%20 in\%2oachebe.pdf?id=2258, October 2016.

Morrell, R. Jewkes, R \& Lindegger, G. (2012). "Hegemonic Masculinity/ Masculinities in South Africa", Men and Masculinities, Vol. 15, No. 1, pp. 11-30.

Nietzsche, Friedrich. (1969). Thus Spake Zarathustra. (R. J. Hollingdale, Trans.). New York: Penguin.

Nnaemeka, Obioma. (1995). "Feminism, Rebellious Women and Cultural Boundaries: Rereading Flora Nwapa and Her Compatriots", Research in African Literatures, Vol. 26, No. 2, pp. 8o-113.

Nwankwo, Chimalum. (2001). "Historicity and the Un-Eve-ing of the African Woman: Achebe's Novels". In D. Okafor (Ed.) Meditations on African Literature, Westport: Greenwood Press.

O’Neill, D. (n.d.). “Things Fall Apart: The Gender Debate", The Imperial Archive, School of English, Queen's University of Belfast, http://www.qub.ac.uk/ schools/SchoolofEnglish/imperial/ nigeria, Accessed September 2016.
Rippl, Gabriele. (2011). "Merit, Justice, Gratitude, Duty, Fidelity: Images of Masculinity in Autobiographies of Early Modern English Gentlewomen and Aristocrats". In S. Horlacher (Ed.) Constructions of Masculinity in British Literature from the Middle Ages to the Present, New York: Palgrave Springer.

Salih, Tayeb. (1976). Season of Migration to the North. (Denys Johnson-Davies Trans.). London: Heinemann.

Takieddine-Amyuni, Mona. (1985) "Images of Arab Women in Midaq Alley by Naguib Mahfouz, and Season of Migration to the North by Tayeb Salih", International Journal of Middle East Studies, Vol. 17, No. 1, pp. 25-36.

Tarnas, Richard. (1996). The Passion of the Western Mind: Understanding the Ideas that have Shaped our World View. London: Pimlico.

Viene, Valentina. (2017). "A Literary Hall of Mirrors", Qantara, https://en.qantara. de/content/tayeb-salihs-season-ofmigration-to-the-north-a-literary-hallof-mirrors, Accessed October 2018.

Wakota, John. (2014). “The Making and Remaking of Gender Relations in Tanzanian Fiction", Ph.D. Dissertation, Stellenbosch University.

Whittaker, D. \& Msiska, Mpalive-Hangson. (2007). Chinua Achebe's Things Fall Apart: A Routledge Study Guide. New York: Routledge.

Zaitchik, Matt C. \& Mosher, Donald L. (1993). "Criminal Justice Implications of the Macho Personality Constellation", Criminal Justice and Behavior, Vol. 2, No. 3, pp. 227-239. 